\title{
THE THEORETICAL-METHODOLOGICAL PROBLEMS OF GENDER-ROLE IDENTITY OF ADOLESCENTS
}

\section{Osmanova A. M.}

\section{INTRODUCTION}

The continually changing living conditions in Ukraine and the modernization of the educational system lead to the necessity for studying the classical system of pedagogic and education. The aims of this studying are a search for new approaches to the education of development generations, creating conditions for the formation of children as fullfledged personalities and as representatives of a certain gender.

A problem of sex-role socialization of adolescents has appeared in psychology for recent decades. In the context of this problem, the question of the formation of notions about sex-role behavior of adolescents starting from preschool age is considered. Reframing of the relationship of genders, self-awareness as a representative of a certain gender, identification of man or woman, and choosing a behavior model by their sexual status carry out in this period.

The study of problems concerning the teenager's characteristic as a representative of a certain gender, the forming of his sex-role behavior contributes to the most harmonious development of personality, individuality, interests, and the system of representing oneself as a man/woman. These characteristics have specific needs, motives, value orientations, and corresponding to these entities forms of social behavior.

Age of adolescence is the determinative period in the formation of a personality. It is characterized by a reframing of the relationship of genders, sex-role behavior as a value that affects the formation of the female / male individuality of the adolescent, his future intimate and social life, family happiness.

This is the time when a subject seeks to expand and clarify the meaning of his/her "I am". This age period period is an important stage in the formation of gender identity, because it is at this age that an active awareness of the essence of their attitudes towards other people and of 
oneself takes place, and sexual self-determination is expanded and clarified.

As scientists emphasize, the formation of gender identity occurs precisely in adolescence which is an internal experience of their sexual identification, the acquisition of a gender-role and modeling to it, a peculiar unity of sexual self-awareness and behavior. Age of adolescence determines the further development of the personality, orientation to the true samples of I am - a man and I am - a woman in the new changing conditions. The formation of gender self-consciousness is included filling of their egalitarian values, sexual "I-concept" and gender-role identification.

The different aspects of gender are considered in national science. Thus, the works of T.L. Bessonova, M.Y. Boryshevsky, O.L. Kononko, G.S. Kostyuk, O.G. Sukhoelova are devoted to the formation of sexual consciousness and identity of a person at different age stages. The questions about the development of the psychological gender are studied in the works of V.V. Avramankova, T. V. Govorun, O.M. Kikinezhdi, A.A. Palia, T.I. Yrefova. The interpersonal relations are highlighted in the works of V.E. Kagan, Y.L. Kolominsky, L.I. Moroz. In the works of Y.E. Alyoshina, V.O. Vasyutinsky, A.S. Volovich, T.S. Gurlieva, I.V. Romanova, V.G. Romanova, the problems of gender-role identity of adolescents were studied.

At the same time, the urgent issues remain a problem of factors of the formation of gender identity identification among adolescents and under the influence of which factors the formation of gender identity identification of adolescents is. The traditional system of values is characterized by a dichotomous vision and a new, egalitarian, is characterized by a combination of interchangeable qualities. For this reason, the role of the social environment (family, peers, and teachers), the content of specialized education, the content of teaching modes, in particular, school textbooks, and internal motivations as factors of gender identity of a person obtain specific meaning.

\section{Psycological theories about the mechanisms of gender-role identiy of adolescents}

In the identity space of a person, the understanding that this world is system integrity is essential. 
The history of the development of the concept of Identity is connected with the development of general philosophical and psychological approaches to the problem of individual rights formation. This is connected with searching for the reason for existence, awareness of its place and role in society, his/her similarity and distinction from other people.

The identity problem is complex and multi-disciplinary. The evolution of the concept of Identity has a specific history in science since its study took place in various sciences - philosophy, sociology, psychology, anthropology, cultural studies, ethnology, etc.

The term Identity was used in the social and humanities sciences and parallel with philosophy for a long time.

The content of the evolution of the concept of Identity in philosophy has a peculiar history that affected its modern understanding. The concept of Identity is philosophical and refers to metaphysical issues. In this meaning, the concept the Identity is used e.g. by B. Spinoza. According to B. Spinoza, the Identity "is not the cause of the Universum but itself is the Universe"1.

The concept of Identity is studied also in psychology. Psychologists who discuss the problem of identity tend to consider two aspects: personal identity and cultural identity.

The current psychological studies of the gender problem are based on the gender factor that is present both at earlier and the latest age period of human life. That means this exists as an extremely stable and constant characteristic of human ontogenetic evolution. The human ontogenesis is revealed as a continuous change of one age period to another and this is one of the permanent characteristics of each of them. The gender is the first sign which an individual enters by the "human realm" with. The object of the study "sex" of the complexity and ambiguity is due to the mosaic of biological, social, and individual-personality aspects that appeared in these prospects and predetermine his internal contradictions ${ }^{2}$.

It can be distinguished in three main areas of research related to gender issues in the framework of psychological science. The first area, socalled gender is based on the study of objectively existing sexual differences in psyche and behavior. The concept of Gender means sex as a

\footnotetext{
${ }^{1}$ Спиноза Б. Избранные произведения [Текст] : Пер. с лат. / Б. Спиноза. - Ростов-на-Дону : Феникс, 1998. $-606 \mathrm{c}$.

2 Москаленко В.В. Гендерна роль як фактор статеворольової соціалізації // Теоретико-методологічні проблеми генетичної психології: Матер. Міжнар. наук. конф. - К. : Міленіум, 2002. - Т. 1. - С. $128-136$.
} 
social phenomenon, like all social that is formed over the biological sex. The sociological and cultural factors in the formation of sexual differences are studied in psychology that should be reflected in scientific research tools. This gives the foundation to claim that in defining the differences between male and female qualities in psychology is better to give preference to the concept of Gender. So, Gender is a socio-psychological concept that defines the status of a person from the prospects of masculinity or femininity. Masculinity is a set of features that distinguish a man from a woman. Femininity is a set of features that distinguish a woman from a man.

The main subject of research in the second area is the subjective stereotypes of masculinity and femininity within a particular Ethno and social culture. The third area of studies is devoted to the formation of gender-role identity and identification as one of the aspects of personal development which is understood as the unity of behavior and selfawareness of an individual who relates to a particular gender. Gender-role identity is a valuable identification of oneself with representatives of a certain gender, peculiar of their behavior and performance of social roles. Socio-sanitary regulations and norms of behavior are internalized by the subject of activity in the process of ontogenesis, gaining subjective understanding, experiences of gender-role which demonstrates in the unity of behavior and self-consciously ${ }^{3}$. Gender-role identity is formed gradually in the process of gender-role socialization. The critical stage of the formation is the age of adolescence. The final formation of it takes place during this period.

The term Identification (from Latin identificare - identify) was introduced by S. Freud for the first time in the theory of him it has two meanings: 1) on the one hand - as the formation of the identity between images that are born in hallucinations dissatisfied instincts, on the other hand - as images of real objects that really satisfy human needs; 2) in the second sense, the identification is understood as one of the essential mechanisms for the formation of personality - the moral authority of super-ego. To overcome instincts and thereby avoid punishment, a child identifies himself partially with his parents or authoritative people, and this

\footnotetext{
3 Кізь О.Б. Гендерна соціалізація депривованого юнацтва:дослідження соціально-психологічних детермінант // Зб. матеріалів Всеукр. науково-практ. конференції. - Тернопіль : “Богдан”, 2003. C. $78-85$.
} 
way internalizes their values, moral norms, prohibitions, and appropriate forms of behavior ${ }^{4}$.

The authors Andreeva G.M. and Petrovsky P.A. consider the term Identification in psychology as a mechanism of socialization, shown in the acceptance of the individual social role in the process of entering the group, the awareness of group membership, and the formation of social institutions 5 .

According to the theory of behaviorism, G.M. Andreev confirms that the identification is the conscious or unconscious copying of attributes or characteristics of others. A positive contribution to the development of the theory of the identification was the introduction of cognitive aspects in the analysis of this process, or rather, recognition of it as consciousness. In the theory of behaviorism, components of identification are taken into account not only biological and psychological but also social. The identification this is the result of the necessity for communication at all levels (unconscious and conscious), direct experience of a subject of identity with an object ${ }^{6}$.

In Psychological Dictionary by the edition V.P. Zinchenko, B.G. Mescheryakova identification is defined as a multiple-meaning psychological concept:

"1) Modeling (unconscious as a rule) oneself to a significant other as a sample based on an emotional connection with it;

2) Identifying oneself with the character of imaginative writing, through which penetration into the semantic content of the work and its aesthetic experience occurs;

3) The mechanism of psychological protection consists of the unconscious likeness of the object;

4) The projection - attribution of his features, motives, thoughts, and feelings to another person;

5) Identifying oneself with some social group or community, accepting of its goals and values, and becoming aware of its membership",

In the psychological literature, the terms Identity and Identification are used sometimes synonymously. E. Erickson considered identity formation

\footnotetext{
${ }_{5}^{4}$ Фрейд 3. Введение в психоанализ. Лекции. Пер. с нем. М.: Наука, 1989. - 455 с.

5 Андреева Г.М., Петровская П.А., Богомолова Н.Н. Современная социальная психология на Западе (теоретические направления). - М.: Изд-во МГУ, 1998. - 271 с.

${ }_{7}^{6}$ Андреева Г.М. Социальная психология. - М. : Наука, 1994. - 324 с.

${ }^{7}$ Психологический словарь / под ред. В. П. Зинченко, Б. Г. Мещерякова ; 2-е изд., перераб. и доп. - М. : Педагогика - Пресс, 1996. - 440 с.
} 
as a synthesis of previous personality identities noted that identity can not be reduced to a set of identities ${ }^{8}$.

B.D. Parygin uses the term Assimilation refers to the identification. He understands the identification of the mutual assimilation of people to each other ${ }^{9}$.

M.Y. Boryshevsky considers identification as a process by which one subject is likened to another by taking on the values, settings and life experience of a model, and its specific forms of behavior ${ }^{10}$.

B. Porshnev asserts the mechanism of group identification is demonstrated that a person is formed by a system of rules and norms which s/he identifies with. Each person refers to a particular social group, identifies his/her "I am" with the other "I am" in the general "We are". As a result, the members of the group of the psychological mechanism of identification have a sense of "We are" that is, that confirm a certain social set and causes its members' similar motives and acts of conduct ${ }^{11}$.

According to the findings of an American researcher P. Massen, identification is different from mere imitation as follows:

1) When identifying digested non-discrete acts of behavior and integrated pattern of behavior;

2) Identification occurs spontaneously without direct reinforcement;

3) The behavior that the individual acquires during the identification process is quite stable;

4) Identification is based on an intimate personal relationship with a model.

Gender identification is most deeply studied in the psychoanalysis of $Z$. Freud who is one of the first scientists emphasized the importance of the sexual sphere in the human psyche. He tried to trace the path of sexuality development in the ontogenesis of a person. In each of the stages of psychosexual development of personality by S. Freud, erogenous zones are established as a focus of his/her desire. The way they will be satisfied will depend largely on problems in the sexual behavior of an adult. The childhood lays the foundations of the psychology of sexuality especially an infant up to six years when the individual passes three of the five stages of

\footnotetext{
8 Эриксон Э. Идентичность: юность и кризис / Пер. с англ. ; общ. ред. и пред. А.В. Толстых. - М. : Прогресс, 1996. - 341 с.

9 Парыгин Б.Д. Социальная психология: проблемы методологии, истории и теории. - СПб. : ИГУП, 2011. - 592 c.

10 Боришевський М.Й. Психологічні питання статевого виховання учнів // Проблеми викладання курсу етика і психологія сімейного життя. - К. : Наука, 1990. - С. 13-29.

${ }^{11}$ Поршнев Б.Ф. Социальная психология и история / Поршнев Б.Ф. ; 2-е изд. - М. : Наука, 2009. - 232 с.
} 
psychosexual development. If the previous stages of a person's psychosexual development were associated with their physical "I am", then from age of adolescence the child's narcissism or auto-erotism disappears, giving way to the direction of sexual interests to other people. They are as objects of sexual satisfaction that contribute to the development of sensuality, attraction, needs, interests of an adult that is, "secondary sexuality". According to the studies of S. Freud, an individual passes in his/her development from one psychosexual stage to another only in ideal conditions of upbringing ${ }^{12}$. He considered that a person develops in that way harmoniously and fully when she follows the mentioned above models and her sexual identification is not violated.

Consequently, identification is interpreted in psychoanalysis as an unconscious process of imitating behavior or certain qualities of the person which an individual identifies with. The traditional psychoanalytic concept ascribes the main role in sexual differentiation to biological factors and considers its basic mechanism of identification of a child with parents.

G. Freud, like her father, emphasizes that a child simulates the behavior of adult representatives of his/her gender unknowingly, primarily of his/her parents. G. Freud pays attention to the complex mechanisms of protecting his "I am" in her works as well. This mechanism includes introjection and projection. Projection is the process of ascribing by a subject to another person his/her thoughts, rice, motives, and feelings that cause the subject to feel guilty and anxious. Introjection is a personification of the personality traits of another person in the individual form. G. Freud described youth as a period of internal conflict, mental unbalance, and restless behavior. The contradictory behavior of adolescents is caused by internal conflicts that are accompanied by sexual changes in the body. One of the most noticeable changes occurring in the puberty period is the increase in instinctive attraction. The main source is puberty which is accompanied by an increase of interest to the sexual area. Impulses "It is" are aggravated and give rise in adolescence and challenge to "I am" and "Over me" of an individual. Thus, in the puberty period, it seems that the infantile sexuality and aggressiveness of early childhood are reviving. It is necessary that "Over me" has enough time to develop in the latent period for the harmony between "It is", "I am" and "Over me",

\footnotetext{
12 Фрейд 3. По ту сторону принципа удовольствия. Пер. с нем. / Сост., послесл. и коммент. А.А. Гучнина. М.: Прогресс, Литера, 1992. - 567 с.

${ }^{13}$ Фрейд 3. Введение в психоанализ. Лекции. Пер. с нем. М.: Наука, 1989. - 455 с.
} 
K. Horney has made a significant contribution to understanding the role of psychosexual development of a child, in the occurrence of sexual dysfunctions, and pathopsychological conditions of an adult. According to her opinion, the parental and children's relationship forms anxiety, fears, and fears of a child at an unconscious level. The author believes that the identification mechanism with his/her father is the cause of the appearance of masculinity in women. Two factors inhibit the formation of a stable libido fixation of a father. Firstly, it is a frustration in a father. Secondly, these are anxiety and feelings of guilt towards the mother for incestuous fantasies. Therefore, the heterosexual libido regresses frustrating and a girl goes from femininity and gains masculine features - complex masculinity is formed ${ }^{14}$.

According to K. Horney, 1) femininity arises on the path of transformation of masculinity; 2) to refuse femininity is possible only through the acquisition of masculine feature; 3 ) female masculinity is secondary in its genesis in relation to femininity; 4) the presence of male feature in a woman is the result of a deviation from normal development.

According to K. Jung's concept, the concept of bravery-femininity is regarded as indicators of the maturity-immaturity of an individual. As a result, the feminine identity is the primary that an individual should be breaking free in the process of his/her development. There are relations of opposition between these structures that can vary from confrontation and struggle to harmony. The feminine in the concept of $\mathrm{K}$. Jung is considered as a characteristic of a neurotic relationship with a mother. An individual with infantile guidance, strong parental imago reveals weakness, helplessness, attachment to the mother and self-identification with her.

Another aspect of gender-role identity in K. Young's concept is related to the archetypes of Anima and Animus (a female part in a male and a male in a female). If a man feels that his mother has hurt him, his Anima will often be in a depressed and annoying mood, a sense of uncertainty and insecurity, abusive, and injurious. If a man can overcome such negative adversities that cause pain then it may even become in his favor and enhance his masculinity. On the other hand, if a man had a positive experience in dealing with his mother, this could also affect his Anime. A man becomes either "feminine - sensual" or sensitive untouchable. K. Jung noted that the cultural stereotype of society focuses

${ }^{14}$ Хорни К. Женская психология. - СПб. Питер, 2011. - 382 с. 
on the development of the appearance of only one face "I am". However, a person is approaching the natural "I am" only discovering the opposite sexually-oriented qualities ${ }^{15}$.

In the concept of "striving for power" by A. Adler, the weakness is equal to femininity and force - masculinity. At the same time, both genders attempt to overcome the feeling of disability and inferiority that is demonstrated in the form of hyper compensation as a "masculine process".

E. Erickson considers psychosocial identity and defined it as a necessary condition for preserving the individual's health, his/her inner integrity, and stability is an important personal need. He distinguished the term psychosocial identity as a result of interaction between society and personality. Studying the approaches of identification, E. Erickson pays attention to a problem of the formation of personality, emphasizing the importance of the fifth stage of development the crisis of adolescence. The re-orientation of a person from the family to society as a whole occurs during this period.

An important place in the psyche of a young person is his/her interest in the thoughts of other people to what they think of themselves. E. Erickson believes that communication with the environment that occurs in this period varies between the positive pole of the identification "I am" and the negative pole of "confusion of roles". In other words, a young man faces the task to unite all that he knows about himself as a student, son, athlete, friend, etc.

All these roles he should combine into one unit, comprehend it, unite with the past and project the future. If a young person copes successfully with this task of psychosocial identification, then he will have a sense of who he is, where he is, and where he goes. If he cannot solve the problem of identification and to define his "I am" due to a difficult childhood or a difficult financial situation, then he begins to show symptoms of confusion of roles and uncertainty about who he is and which environment he belongs to. Such confusion of roles leads to conflictual behavior, antisocial actions, and the growth of crime among young people.

So, according to E. Erickson, identity is a characteristic feature of an individual, "internal identity and continuity" is synthesized with the desire to integrate it with social structures ${ }^{16}$.

\footnotetext{
${ }^{15}$ Юнг К.Г. Архетип и символ. - М. : Рениссанс, 1991. - 304 с.

16 Эриксон Э. Идентичность: юность и кризис / Пер. с англ. ; общ. ред. и пред. А.В. Толстых. - М. : Прогресс, 1996. - 341 с.
} 


\section{Socio-psychological bases of formation of gender-role identity of adolescents}

A family is an educational cradle of a person. It forms not only the physical but also the social life of a child. Therefore it is the primary, most influential and long-term approach of the formation of gender-role identity of the child at all stages of child development.

Considering the educational strategies of parents about teaching a child his/her gender-role, parents act in this case primarily as members of a certain cultural tradition regarding the place of a man and a woman in society. It includes an established system of differentiation of gender-roles that is the gender division of labor, specific gender-regulations, the rights and responsibilities of men and women, and the associated system of stereotypes of masculinity and femininity representations of what should be men and women.

The uniqueness of the family's influence the development of gender identity is confirmed by those children who are deprived of a family. There are the following images of masculinity. Femininities are formed primarily because of the inclusion in every day family's relationships, direct imitation and assimilation of the experience of performance of fathermother roles, through the correlation of his/her behavior with gender-role regulations. Charity children deprived of permanent parental care, usually synthesize images of masculinity/femininity from media, relationships with adult educators, and experience with peers. The limitation of their social experience impoverishes the range of social situations in children development. This simplifies the system of interpersonal relationships important for the child and thus distorts the logic of the formation of the gender-role image "I am".

Regarding the psychological differentiation of gender, A. Adler observes the following. The normal, harmonious interpersonal relationships undoubtedly are based on adequate attitudes towards the images of masculinity-femininity. It depends not only on how much time the parents give to the child, raising his/her as a woman or a man but first of all how much a person is developed socially, his/her ability to contact with others is formed, understanding others, and to "feeling" others.

The family life is a life sphere that set high conditions of psychological culture, responsibility, level of development of selfreflection, marital, maternal and parental roles. Children from families have the opportunity to participate in complex, diverse activities, and 
communication of adults. The assimilation of all complex elements of activity, the development of the internal plan of actions goes beyond the educational situation and is included in the context of activities directly attractive to the child. Charity children deprived such a variety of emotionally-rich interaction with adults.

Some aspects of the family, including ethical, psychological, and pedagogical were covered in the studies of M. Olexyeva, T. Govorun, O. Kikinezhdi, O. Kiz, Z. Kisarchuk, V. Kravets, O. Nasonova, V. Stakhnevych, etc. Such important aspects of the development of the sexual consciousness of depressed adolescents as the formation of representations about the basic functions and types of the family, the relationships between parents and children did not find a deep theoretical and experimental substantiation, and in the future still remain poorly researched in the problems of age and pedagogical psychology.

To understand the meaning of differential gender identification, it is necessary to trace its dynamics through the prospect of family relationships. I. Kon considers that knowledge about his sexual identity is formed at the age of 1.5 years and since then plays the role of the most constant, core element of self-consciousness. Each age stage brings the changes in the content of this identity which is primarily referred to the mental and intellectual development of the child.

Researching the age aspect of identifying children from 3 to 16 years old from complete families, O.I. Zakharov showed a clear difference in the sensitivity of children of different ages and sex to the influence of the parent of the same sex. In his opinion, children of both sexes who are raised without a father, more often than children from a complete family, demonstrate conflict in behavior, mood changings, stubbornness, attempts to stand out, dependence and passivity.

The researcher notes that the age of the most intense identification with the parents of the same sex is 5-7 years for boys and a longer period 3-8 years for girls. The identification of girls with same-sex parents from boys has the following characteristics: the greater the intensity of the identification process that is girls choose the role of the mother more often than boys choose the role of the father; the greater importance of identification for girls emotionally warm relationships with the mother; the greater dependence of girls identification from the nature of the relationship between parents, when the mother-father conflict negatively affects the identification of girls with their mothers. The process of identification is suspended during the period of 
intense self-development - from 9 years for girls and 10 - for boys. This leads to emancipation from parental authority.

The psychological studies prove that a 3-4-year-old child distinguishes consciously between genders of people around him/her but more often refers it to external signs only. A 6-7-year-old child realizes finally the invariability of sexual identification. Thus, even in the period of preschool childhood, children are sufficiently aware of gender differences in toys, clothing, activities, objects, and occupations. As the child grows up, s/he notices the differences between the sexes. As a rule, s/he has increased attention to role models of the same sex as $s / h e$ is and s/he wants to be a "real and the best" boy or girl ${ }^{17}$.

According to E. Maccoby and C. Jacklin, children receive information from representatives of both genders but they are inclined to reproduce only those patterns that are inherent in their gender. According to the authors, this model accurately reveals gender-role behavior. Therefore, even the children of those parents who demonstrate the atypical behavior of a gender stereotype can perceive and imitate models typical of their gender-roles. The gender stereotypes are as approaches for maintaining gender-specific differentiation.

As researched I. V. Telniuk, the majority of parents (83\%) consider it necessary to educate their children in the context of sexual differentiation, the rest hesitate to identify the right ways ${ }^{18}$.

In the work of V.O. Vasyutinsky, there is evidence that the genderrole identity of children is not so much the result of conscious and purposeful interference by parents as the derivative of the whole intrafamily atmosphere. The author pays attention to the differences in the identification of maternal and parental love of the child. Maternal love is unconditional, global, and permanent. Certainly, because the mother loves his/her child in spite of everything, she loves it because it's her baby. This love demonstrates in each situation regardless of circumstances. This is constant and lasts through the whole life. At the same time, the father loves the child more distantly. In his opinion, he loves his/her when s/he has something to be loved to when s/he justifies his hopes and ideas. In the author's opinion, it's harder for men to love the child "for no reason", just

\footnotetext{
17 Захаров А.И. Психологические особенности восприятия детьми роли родителей // Вопросы психологии. - 1982. - № 1. - С. 59-68.

18 Тельнюк И.В. Индивидуально-дифференцированный подход к организации самостоятельной деятельности девочек и мальчиков 5-6 лет в детском саду: автореф. дис. ... канд. наук: - СПб., 1999. - 20 с.
} 
because it's their child. Maternal love is selfless but also subjective. The father can assess the nature objectively and abilities of the child ${ }^{19}$.

I.S. Kon focuses on the differences in parental and maternal influence on the formation of the child's characteristics. The father is perceived and is indeed tougher and authoritative than the mother, especially as regards boys and young men. Psychological intimacy with his father is observed less often than with his mother. The influence of the father on the upbringing of children in most families is lower than the influence of the mother ${ }^{20}$.

According to S. Bem, educating the "a real boy", the parents approve of the features of practicality, perseverance, self-confidence, and stiffness. "True girl" is educated gentle, dependent, sensual, coquettish and impractical.

Petrovsky O.V. believes that when children are relative free from the stiffness of gender typing, they demonstrate a richer behavioral set and more prosperous psychologically. Understanding the gender-role by a boy or girl facilitates in the future their socialization in society. At the same time, we find that children whose behavior is strictly suited to the requirements of their gender-roles are often characterized by lower intelligence and less creative abilities ${ }^{21}$.

Authors Y.E. Alioshina, O.S. Volovych believes that the barriers for boys' identification are a long term of contact between a boy-son with his mother that makes his father an undesirable, little-known object for identification. This can happen even when the child is afraid of his father because of his excessive severity, rudeness - then he will desire to get the needed warmth and attention from his mother, neurotic dependent on her and her behavior style ${ }^{22}$.

As a result, the identification is primary with the feminine mother. The status of the child reflects traditionally a female feature- dependence, subject position, passivity. Thus, a boy faces a difficult task in future development - to change the primary female identification to masculine. However, most of the behavior models that the boy faces in the process of formation of gender-roles are feminine: nurseries of children garden,

\footnotetext{
${ }^{19}$ Васютинський В.О. Особливості статеворольового самовизначення хлопчиків-підлітків із неповної сім’ї: Автореф. дис. ... канд. псих. наук: 19.00.07 - К., 1992. - 19 с.

${ }^{20}$ Кон И.С. Психология половых различий // Вопр. псих. - 1981. - № 2. - С. 47-57.

21 Петровский А.В. Личность. Деятельность. Коллектив. - М. : Политиздат, 1982. - 255 с.

22 Алешина Ю.Е., Волович А.С. Проблемы усвоения ролей мужчины и женщины // Вопросы психологии. - 1991. - № 7. - С. 74-82.
} 
doctors, and teachers. Therefore, boys have limited identification of a true male gender-role and the behavior that it responds to.

According to R.F. Harley, this leads to the idea that boys have to build their own sexual identity, mainly based on denial and negative attitudes towards "women's" world: not to be like girls and not to engage in women's activities. This explains the fact that girls the gender-role identity is less conflictual and continuous.

According to Y.M. Nabiulina, identification is more successful of girls: $43 \%$ of girls compared to $8 \%$ of boys have a high degree of identification with the parents of their gender. According to the author, there is inadequate, misunderstood identification more often of boys that is related to the absence of a father in the family ${ }^{23}$.

F. Parsons saw the role of the father in helping his son overcome the primary dependence on the mother from early childhood. There is the destruction of the primary identification of the boy with his mother which occurs with the help of his father, who maintains his son's tendency to depreciate the entire female.

The traditional male role affects paternity adversely and the frequency of emotional contacts. The demonstration of tenderness, affection, and care are not available for many parents due to the dominant gender stereotype of masculinity which denies the expressiveness of relationships as a deviation from the male role.

G. Russell proved that androgenic parents more actively and constantly engaged with their children that are those who have the same male and female peculiarities of behavior.

Gender stereotypes play an important role in parent's strategies in the education of children, the expectations of their success in learning, the choice of the future profession, etc. J. Eccles argues that parents keep gender-differentiated awareness of their children's abilities and can socialize gender differences of self-perception, interests, and skills of children through educational impacts. It has been proved that parents observe gender-differentiated awarenesses of their children's abilities, even when their different-sex children receive the same grades at school and have equal grades taking standardized tests. J. Eccles refers to studies that have proven that parents explain the successes of boys and girls in a

\footnotetext{
${ }^{23}$ Набиулина Ю.М. Проблема полоролевой идентификации в семейном аспекте // Психология XXI века: Тезисы международной межвузовской научно-практической конференции студентов и аспирантов. - СПб. : Изд-во СПб. ГУ, 2001. - С. 238-239.
} 
particular school subject for various reasons: parents of boys who succeed in mathematics believe that such a result is achieved through their abilities, while the parents of girls are excellent mathematical achievements associated with their diligence ${ }^{24}$.

There is a certain model that parents have laid down and which is based on gender stereotypes. According to this model, gender stereotypes influence significantly:

1) Why parents attribute the school achievements of their children (abilities, diligence);

2) The emotional reactions of parents about the success of children in various fields of knowledge;

3) The importance that parents attach to their children with different knowledge and skills;

4) The advice given by parents to children in obtaining by them certain knowledge and skills;

5) Those activities to which parents involve their children and the toys that they buy them.

The gender-role of adolescents as one of the most common approaches for teaching gender-role behavior is confirmed and specified in communication with parents. I. Kon identifies the following approaches:

1) Reinforcements: encouraging certain behaviors parents consider to be correct and punishing for deviancy, parents enroot into a child's consciousness a certain system of rules, the observance of which becomes a habit eventually;

2) Identification: the child follows the parents, strives to become as they are;

3) Understanding: knowing the inner world of a child and meeting his/her needs, by that the parents form their personal qualities;

4) The role-complementarity: for instance, if parents have no qualities in a family, these qualities are produced by a child, circumstances require (in a family where a mother is helpless, the role of the hostess serves an elder daughter);

5) The approach of psychological counteraction: a child whose will is strictly limited can create an attraction to independence and that one whom everything is allowed may grow up a dependent person ${ }^{25}$.

\footnotetext{
${ }^{24}$ Eccles J.S. Gender roles and women's actievement-related decisions // Educational Researcher. 1986. N 15. - Pp. 15-19.

${ }^{25}$ Кон И.С. Психология половых различий // Вопр. псих. - 1981. - № 2. - С. 47-57.
} 
The studies of A.Y. Vargas proved that acceptance or neglect of a child is the main place in the structure of parental attitude. It is emphasized that indeed a complete and harmonious family is instrumental in the formation of the child's psychological sex for the formation of adequate gender-roles, stimulates the process of identifying a child with a person of his/her gender - primarily with his/her father or mother ${ }^{26}$.

According to Western authors M. Lewis and L. Rosenblum, mothers relate to the behavior of sons more reluctantly and allow them to be more aggressive than girls. Boys are punished physically more often. Y.E. Aleshina and O.S. Volovich have found in their studies that parents demand a lot from their sons, as a result, receive greater distance their sons from parents ${ }^{27}$. As the study of A.S. Baranik, the mothers are responsibilities for the daughters and the father - for the sons ${ }^{28}$.

O.B. Chirkova has proved that a father plays a more significant role in forming the motivation in achievements of daughters: the daughters of mothers who work at institutions or a factory are more motivated in a career than their peers whose mothers are housewives ${ }^{29}$.

According to V.P. Svetlakova and M.O. Tokmakova, the interesting is the fact, that choosing the profession children are consulted more often with their mother than with their father ( $40 \%$ and $23.7 \%$ respectively $)^{30}$.

There is an argument as soon as children become able to identify their gender, they have the motivation to be or become like other members of the very first reference group in their lives - families. They begin to monitor carefully adult' behavioral patterns. On the other hand, their parents also direct their educational efforts to implant the sons and daughters of the model of behavior and the basic concepts of "gender" ideology. Their potential of gender representations and the demands of a society of socialization of women and men are involved in this process.

Thus, gender-role education in the family is differentiated noticeable by gender which creates unequal opportunities for representatives of

\footnotetext{
${ }^{26}$ Варга А.Я. Идентификация с родителями и формирование психологического пола // Семья и формирование личности: Сборник научных трудов / Под ред. А.А. Бодалева. - М. : АПН СССР, 1981. C. $10-15$.

27 Алешина Ю.Е., Волович А.С. Проблемы усвоения ролей мужчины и женщины // Вопросы психологии. - 1991. - № 7. - С. 74-82.

28 Баранник О.С. Влияние семьи на формирование тревожности у дошкольников // Ананьевские чтения - 99: Тезисы научно-практической конференции. - СПб., 1999. - С. 176-177.

29 Чиркова О.Б. Роль детско-родительских отношений в развитии ответственности подростков // Психология XXI века: Тезисы Междунар. межвуз. научно-практ. студенческой конференции. - СПб., 2000. - C. 193-195.

${ }^{30}$ Светлакова В.П., Токмакова М.А. Влияние родителей на выбор абитуриента // Ананьевские чтения2001 : Тезисы научно-практической конференции. - СПб., 2001. - С. 413-414.
} 
different sexes: in general, boys have more opportunities to expand their experience, to explore, and experiment. Activity, independence, and selfcontrol in a rivalry situation encourage. In the process of learning girls of gender behavior, her activities are limited, the emphasis is on the correct behavior, there is always parental control: work at home, closer to parents, frequent and unconditional help create for the girls a more canonized and predictable environment than that in which the boys live.

A school is a major aspect of social factors. The school is one of the most conservative systems. Therefore, some foundations reproduce patriarchal ideas about the purpose of men and women at the level of secondary school. They form different orientations for the further formation of gender-role identification of adolescents. The most popular and persistent features of a personality that are demonstrated in the social activity which is regulated by the role structure of society are formed at school in the process of education and upbringing. Girls and boys learn common values, gender instructions of teachers, and as a result, the inheritance of gender stereotypes becomes a part of their gender structure.

\section{CONCLUSIONS}

The analysis of the theoretical and methodological approaches in studying the problem of the formation of gender-role identity allows us to outline a set of conceptual conclusions.

1. In psychological and pedagogical literature is given a significant place of the gender-role identity of a person. The most intense form of gender-role identity occurs in the age of adolescence. However, the problem of socio-psychological conditions that affect the formation of adolescents' gender-role identification is still poorly understood and very generalized. The analysis of the literary sources concludes that identification is always co with other people who can serve as a pattern for a short or long period. In the early stages, the approach of gender-role identity ensures the transfer of "personal" experience indirectly - through a personal example, imitation, and suggestion. The range of people from whom the sample-object of identification is selected expands at the later stages of the formation of gender-role identity. It is not only parents but also peers, teachers, etc.

2. The isolated social conditions conclude that family forms not only the physical but also the social life of a child. Therefore, this is the 
primary, most influential, and long-term active force of the formation of the gender-role identity of a child at all stages of its development. The analysis of scientific sources confirms that family upbringing differentiates based on gender and creates unequal opportunities for representatives of different genders.

3. School is a major aspect among social conditions for the formation of gender identity. The most widespread and persistent features of the personality which are showed in a social activity that is regulated by the role structure of society in the educational process and upbringing are formed in school.

4. In psychological and pedagogical literature, a significant place in the formation of the "I am-concept" of a teenager's personality which is a kind of framework that gives various psychological demonstrations of a person a certain internal interdependence. It takes a significant place, directing it into a united place, so all of this becomes a basis, an example, a model for choosing by a boy and a girl of gendered behavior in meaningful spheres of life activity.

Based on the conducted theoretical analysis and generalization, a personality-gender approach to studying the conditions of the gender-role identity of adolescents is suggested. This is carried out through a set of principles.

\section{SUMMARY}

The theoretical and methodological analysis of the formation of gender-role identity of adolescents and the study of socio-psychological conditions affecting its formation are presented in this article.

1. Theoretical analysis of socio-psychological conditions of genderrole identity develops a methodological approach that corresponds to the research tasks most adequately. We use the personality-gender approach which is based on the principles: a) objectivity, parity, integrity in the study and development of gender-role identity; b) the development of gender consciousness and consciousness in activities that are necessary for a proper understanding of the demonstration and development "I amconcept" of a personality, and the development of its gender-roles; c) succession which involves the sequence in the transfer of gender knowledge to young people, their adequacy to the child's age; the gradual expansion of the information gender area in which the authority of the 
source of information (parents, teacher, psychologist, physician) is an important condition for the normal psychosexual development of an individual; d), gender parity on which the "equality formula" creating textbooks is a prerequisite; that involves partnerships and parity opportunities for women and men as subjects of change in social, economic, and political processes; e) preservation of natural expediency of sexually optimal and biologically respective properties of gender belonging personality.

2. The study of socio-psychological factors based on this approach researches the peculiarities of the process of formation of gender-role identity of adolescents and to disclose the conditions necessary for their harmonious development taking into account the person-gender approach.

\section{REFERENCES}

1. Спиноза Б. Избранные произведения [Текст] : Пер. с лат. / Б. Спиноза. - Ростов-на-Дону : Феникс, 1998. - 606 с.

2. Москаленко В.В. Гендерна роль як фактор статеворольової соціалізації // Теоретико-методологічні проблеми генетичної психології: Матер. Міжнар. наук. конф. - К. : Міленіум, 2002. - Т. 1. C. $128-136$.

3. Кізь О.Б. Гендерна соціалізація депривованого юнацтва: дослідження соціально-психологічних детермінант // Зб. матеріалів Всеукр. науково-практ. конференції. - Тернопіль : “Богдан”, 2003. C. $78-85$.

4. Фрейд 3. Введение в психоанализ. Лекции. Пер. с нем. М.: Наука, 1989. - 455 с.

5. Андреева Г.М., Петровская П.А., Богомолова Н.Н. Современная социальная психология на Западе (теоретические направления). - М.: Изд-во МГУ, 1998. - 271 с.

6. Андреева Г. М. Социальная психология. - М. : Наука, 1994. $324 \mathrm{c}$.

7. Психологический словарь / под ред. В.П. Зинченко, Б.Г. Мещерякова ; 2-е изд., перераб. и доп. - М. : Педагогика - Пресс, 1996. -440 c.

8. Эриксон Э. Идентичность: юность и кризис / Пер. с англ. ; общ. ред. и пред. А. В. Толстых. - М. : Прогресс, 1996. - 341 с. 
9. Парыгин Б.Д. Социальная психология: проблемы методологии, истории и теории. - СПб. : ИГУП, 2011. - 592 с.

10. Боришевський М.Й. Психологічні питання статевого виховання учнів // Проблеми викладання курсу етика і психологія сімейного життя. - К. : Наука, 1990. - С. 13-29.

11. Поршнев Б.Ф. Социальная психология и история / Поршнев Б.Ф.; 2-е изд. - М. : Наука, 2009. - 232 с.

12. Фрейд 3. По ту сторону принципа удовольствия. Пер. с нем. / Сост., послесл. и коммент. А.А.Гучнина. М.: Прогресс, Литера, 1992. - 567 c.

13. Фрейд 3. Введение в психоанализ. Лекции. Пер. с нем. М.: Наука, 1989. - 455 с.

14. Хорни К. Женская психология. - СПб. Питер, 2011. - 382 с.

15. Юнг К.Г. Архетип и символ. - М. : Рениссанс, 1991. - 304 с.

16. Эриксон Э. Идентичность: юность и кризис / Пер. с англ. ; общ. ред. и пред. А. В. Толстых. - М. : Прогресс, 1996. - 341 с.

17. Захаров А.И. Психологические особенности восприятия детьми роли родителей // Вопросы психологии. - 1982.- № 1.С. $59-68$.

18. Тельнюк И.В. Индивидуально-дифференцированный подход к организации самостоятельной деятельности девочек и мальчиков 5-6 лет в детском саду: Автореф. дис. ... канд. наук: - СПб., 1999. - 20 с.

19. Васютинський В.О. Особливості статеворольового самовизначення хлопчиків-підлітків із неповної сім'ї: Автореф. дис. ... канд. псих. наук: 19.00.07 - К., 1992. - 19 с.

20.Кон И.С. Психология половых различий // Вопр. псих. 1981. - № 2. - С. 47-57.

21. Петровский А.В. Личность. Деятельность. Коллектив. - М. : Политиздат, 1982. - 255 с.

22. Алешина Ю.Е., Волович А.С. Проблемы усвоения ролей мужчины и женщины // Вопросы психологии. - 1991. - № 7.C. $74-82$.

23. Набиулина Ю.М. Проблема полоролевой идентификации в семейном аспекте // Психология XXI века: Тезисы международной межвузовской научно-практической конференции студентов и аспирантов. - СПб. : Изд-во СПб. ГУ, 2001. - С. 238-239. 
24. Eccles J.S. Gender roles and women's actievement-related decisions // Educational Researcher. 1986. - N15. - Pp. 15-19.

25. Кон И.С. Психология половых различий // Вопр. псих. 1981. - № 2. - С. 47-57.

26. Варга А.Я. Идентификация с родителями и формирование психологического пола // Семья и формирование личности: Сборник научных трудов / Под ред. А.А. Бодалева. - М. : АПН СССР, 1981. C. $10-15$.

27. Алешина Ю.Е., Волович А.С. Проблемы усвоения ролей мужчины и женщины // Вопросы психологии. - 1991. - № 7.C. $74-82$.

28. Баранник О.С. Влияние семьи на формирование тревожности у дошкольников // Ананьевские чтения - 99: Тезисы научнопрактической конференции. - СПб., 1999. - С. 176-177.

29. Чиркова О.Б. Роль детско-родительских отношений в развитии ответственности подростков // Психология XXI века: Тезисы Междунар. межвуз. научно-практ. студенческой конференции. СПб., 2000. - С. 193-195.

30. Светлакова В.П., Токмакова М.А. Влияние родителей на выбор абитуриента // Ананьевские чтения-2001 : Тезисы научнопрактической конференции. - СПб., 2001. - С. 413-414.

\section{Information about the authors: Osmanova A. M.}

Candidate of Psychological Sciences, Associate Professor at the Department of Psychology and Pedagogy of the Educational and Scientific Humanitarian Institute of the V. I. Vernadsky Taurida National University 